\title{
MENCIPTAKAN PEMBELAJARAN EFEKTIF MELALUI HYPNOTEACHING
}

\author{
Muhammad Anwar \\ Institut Parahikmah Indonesia, Gowa, Indonesia \\ e-mail: Muh_anwarhm@gmail.com
}

\begin{abstract}
The aim of this paper is to provide the information to educators on hypnoteaching as one of the alternative methods that can be used to create effective learning. The effective learning is the learning that enables learners to learn easy, fun, and can achieve the learning objectives that have been set. Hypnoteaching is the learning methods in delivering the subject matter, the teacher uses the communication techniques are very persuasive and suggestive with the aim that students easily understand the subject matter. Hypnoteaching steps include: 1) intention and motivation within yourself; 2) pacing or equalize the position, gestures, language, and brain waves with others or learners; 3) leading or directing learners; 4) using positive words; giving a compliment; 6) modeling or exemplify through speech and behavior. If teachers apply hypnoteacing in the learning activities, the classroom atmosphere will be more conducive, learners feel important, safe and comfortable so that the goal of learning more easily is achieved.
\end{abstract}

Keywords: effective, learning, hypnoteaching

\section{Pendahuluan}

Kegiatan pembelajaran di kelas memiliki peran yang sangat penting dalam pengelolaan pendidikan, karena keberhasilan satuan pendidikan dalam mengimplementasikan dan mencapai tujuan kurikulum sangat ditentukan oleh keberhasilan guru dalam mengelola kegiatan pembelajaran di kelas. Oleh karena itu, kegiatan pembelajaran yang meliputi perencanaan, pelaksanaan dan penilaian hasil pembelajaran harus dikelola secara sistematis dan terarah untuk meningkatkan kualitas proses dan hasil belajar peserta didik.

Dalam Peraturan Menteri Pendidikan dan Kebudayaan (Permendikbud) Nomor 65 Tahun 2013 tentang Standar Proses Pendidikan Dasar dan Menengah dinyatakan bahwa pelaksanaan proses pembelajaran yang merupakan implementasi dari Rencana Pelaksanaan Pembelajaran (RPP) meliputi kegiatan pendahulun, kegiatan inti, dan kegiatan penutup. Pendahuluan merupakan 
kegiatan awal dalam suatu kegiatan pembelajaran yang bertujuan untuk membangkitkan motivasi dan memfokuskan perhatian peserta didik untuk berpartisipasi aktif dalam proses pembelajaran. Sedangkan kegiatan inti merupakan serangkaian kegiatan utama dalam pembelajaran yang dilakukan untuk mencapai tujuan pembelajaran. Sementara kegiatan penutup adalah kegiatan yang dilakukan untuk mengakhiri aktivitas pembelajaran, yang meliputi pembuatan rangkuman atau kesimpulan, refleksi, penilaian, umpan balik, dan tindak lanjut.

Ketiga kegiatan tersebut yakni kegiatan pendahuluan, kegiatan inti dan kegiatan penutup merupakan satu rangkaian kegiatan pembelajaran dalam satu pertemuan (tatap muka) yang tidak boleh terputus karena semuanya berpengaruh terhadap pencapaian tujuan pembelajaran. Oleh karena itu, guru harus mampu melaksanakan perannya sebagai fasilitator, komunikator dan motivator dalam mengelola kegiatan pembelajaran agar kegiatan pembelajaran tersebut berlangsung secara efektif.

Dari hasil pengamatan penulis di beberapa sekolah tentang pelaksanaan kegiatan pembelajaran, diperoleh fakta bahwa masih banyak kegiatan pembelajaran di kelas tidak berjalan secara efektif. Indikatornya adalah materi pelajaran yang disampaikan guru tidak terorganisasi dengan baik, peserta didik tidak terlibat secara aktif dalam kegiatan pembelajaran, pembelajaran tidak menarik, serta tidak tercapainya tujuan pembelajaran yang telah ditetapkan. Fakta tersebut sejalan dengan pernyataan yang dikemukakan oleh Sanjaya bahwa salah satu masalah yang dihadapi oleh dunia pendidikan kita adalah masalah lemahnya proses pembelajaran ${ }^{1}$.

Sehubungan dengan itu maka dipandang perlu adanya informasi yang memadai buat para pendidik tentang berbagai pendekatan, strategi, metode serta teknik pembelajaran yang dapat digunakan untuk menciptakan pembelajaran yang efektif. Salah satu metode yang saat ini mulai banyak dikembangkan adalah metode pembelajaran hypnoteaching. Metode ini telah terbukti efektif dalam mengoptimalkan kegiatan pembelajaran di sekolah ${ }^{2}$.

\section{Pembelajaran Efektif}

Dari keseluruhan proses pendidikan di sekolah, pembelajaran merupakan aktivitas yang paling utama. Ini berarti bahwa keberhasilan pencapaian tujuan pendidikan banyak bergantung pada bagaimana mengelola proses pembelajaran

\footnotetext{
${ }^{1}$ Wina Sanjaya,. Strategi Pembelajaran. (Jakarta: Kencana Prenada Media Group, 2007), h. xiii

${ }^{2}$ Ibnu Hajar., 2012. Hypnoteaching. (Jogjakarta:Diva Press, 2012), h. 5
} 
itu secara efektif. Dalam Peraturan Pemerintah Nomor 32 Tahun 2013 tentang Standar Nasional Pendidikan, dinyatakan bahwa "Proses pembelajaran pada satuan pendidikan diselenggarakan secara interaktif, inspiratif, menyenangkan, menantang, memotivasi peserta didik untuk berpartisipasi aktif, serta memberikan ruang yang cukup bagi prakarsa, kreativitas, dan kemandirian sesuai dengan bakat, minat, dan perkembangan fisik serta psikologis peserta didik".

Berdasarkan Peraturan Pemerintah tersebut, maka prinsip khusus dalam pengelolaan kegiatan pembelajaran adalah interaktif, inspiratif, menyenangkan, menantang dan memotivasi. Prinsip-prinsip tersebut oleh Sanjaya ${ }^{3}$ diuraikan sebagai berikut:

Pertama, Interaktif, artinya bahwa mengajar bukan sekadar menyampaikan pengetahuan dari pendidik ke peserta didik, akan tetapi sebagai proses membangun interaksi, baik interaksi antara pendidik dan peserta didik, antara peserta didik dan peserta didik lainnya, antara peserta didik dan media pembelajaran, maupun antara peserta didik dan lingkungannya. Melalui proses interaksi tersebut memungkinkan kemampuan peserta didik akan berkembang baik mental maupun intelektual.

Kedua, Inspiratif, artinya bahwa pembelajaran merupakan suatu proses yang memungkinkan peserta didik untuk mencoba dan melakukan sesuatu. Dengan demikian, informasi dan proses pemecahan masalah yang disampaikan pendidik dalam pembelajaran bukanlah harga mati yang bersifat mutlak, akan tetapi merupakan hipotesis yang merangsang peserta didik untuk mencoba dan mengujinya. Oleh karena itu, pendidik harus membuka berbagai kemungkinan yang dapat dikerjakan peserta didik sesuai dengan inspirasinya sendiri.

Ketiga, Menyenangkan. Proses pembelajaran adalah proses yang dapat mengembangkan seluruh potensi peserta didik. Seluruh potensi itu hanya mungkin dapat berkembang manakala peserta didik terbebas dari rasa takut, dan menegangkan. Oleh karena itu, perlu diupayakan agar proses pembelajaran merupakan proses yang menyenangkan (enjoyful learning). Proses pembelajaran yang menyenangkan dapat dilakukan dengan menata ruangan yang menarik serta mengelola pembelajaran yang hidup dan bervariasi.

Keempat, Menantang. Proses pembelajaran adalah proses yang menantang peserta didik untuk mengembangkan kemampuan berpikir, yakni merangsang kerja otak secara maksimal. Kemampuan tersebut dapat ditumbuhkan dengan cara mengembangkan rasa ingin tahu peserta didik melalui kegiatan mencoba, atau bereksplorasi. Oleh karena itu, informasi yang diberikan kepada peserta didik, hendaknya bukanlah informasi yang

${ }^{3}$ Wina Sanjaya, 2007, Strategi Pembelajaran, (Jakarta: Kencana Prenada Media Group, 20017), 
sudah jadi, akan tetapi informasi yang mampu membangkitkan peserta didik untuk mau mengolahnya, memikirkannya sebelum dia mengambil kesimpulan.

Kelima, Memotivasi. Motivasi adalah aspek yang sangat penting untuk membelajarkan peserta didik. Oleh karena itu, membangkitkan motivasi merupakan salah satu peran dan tugas pendidik dalam setiap proses pembelajaran. Dalam rangka membangkitkan motivasi, pendidik harus dapat menunjukkan pentingnya pengalaman dan materi pelajaran dalam kehidupan peserta didik. Dengan demikian, peserta didik akan belajar bukan sekadar untuk memperoleh nilai akan tetapi didorong oleh keinginan untuk memenuhi kebutuhannya.

Penerapan prinsip-prinsip pembelajaran tersebut diharapkan akan bermuara pada terciptanya pembelajaran yang efektif. Pembelajaran efektif adalah pembelajaran yang dapat memberikan hasil belajar yang bermanfaat dan terfokus pada peserta didik (student centered) melalui penggunaan prosedur yang tepat ${ }^{4}$. Definisi ini mengandung arti bahwa dalam pembelajaran efektif terdapat dua hal penting, yaitu terjadinya belajar pada peserta didik dan apa yang dilakukan oleh pendidik untuk membelajarkan peserta didiknya. Sedangkan menurut Dick dan Reiser bahwa pembelajaran efektif adalah suatu pembelajaran yang memungkinkan peserta didik untuk belajar keterampilan spesifik, ilmu pengetahuan, dan sikap serta yang membuat peserta didik senang ${ }^{5}$. Sementara itu pembelajaran dianggap efektif apabila skor yang dicapai peserta didik memenuhi batas minimal kompetensi yang telah dirumuskan ${ }^{6}$. Misalnya seorang pendidik merumuskan salah satu mata pelajaran dengan standar kompetensi minimal $90 \%$. Artinya semua upaya pembelajaran yang dilakukan pendidik pada akhirnya akan diupayakan peserta didik yang belajar dapat mencapai tujuan belajar minimal $90 \%$ penguasaannya. Jika hal ini diberikan skor angka dengan rentang 1-100, maka setiap peserta didik harus mencapai skor 90. Pencapaian skor ini dianggap pembelajaran yang efektif.

Dari beberapa pengertian pembelajaran efektif sebagaimana uraian di atas, maka dapat disimpulkan bahwa pembelajaran efektif adalah suatu pembelajaran yang memungkinkan peserta didik untuk dapat belajar dengan mudah, menyenangkan, dan dapat mencapai tujuan pembelajaran yang telah ditetapkan.

\footnotetext{
${ }^{4}$ Hamzah B. Uno dan Mohammad Nurdin, Belajar dengan Pendekatan PAILKEM. (Jakarta: PT. Bumi Aksara, 2012), h. 173.

${ }^{5}$ M.Sobry Sutikno, Pembelajaran Efektif, (Mataram: NTP Press, 2005), h. 33

${ }^{6}$ Hamzah B. Uno dan Mohammad Nurdin, Belajar dengan Pendekatan PAILKEM, (Jakarta: PT. Bumi Aksara, 2012), h. 173.
} 
Pembelajaran yang efektif memiliki sejumlah indikator, dan menurut hasil penelitian dan pengkajian Wotruba dan Wright, terdapat 7 (tujuh) indikator pembelajaran yang efektif ${ }^{7}$, yaitu:

Pertama, Pengorganisasian materi yang baik. Pengorganisasian adalah bagaimana cara mengurutkan materi yang akan disampaikan secara logis dan teratur, sehingga dapat terlihat kaitan yang jelas antara topik satu dengan topik lainnya selama pertemuan berlangsung. Pengorganisasian materi terdiri dari: a) Perincian materi; b) Urutan materi dari yang mudah ke yang sukar; c) Kaitan materi dengan tujuan pembelajaran.

Kedua, Komunikasi yang efektif. Kecakapan dalam penyajian materi termasuk pemakaian media dan alat bantu atau teknik lain untuk menarik perhatian peserta didik merupakan salah satu karakteristik pembelajaran yang baik. Komunikasi yang efektif dalam pembelajaran mencakup penyajian yang jelas, kelancaran berbicara, interpretasi gagasan abstrak dengan contohcontoh, kemampuan wicara yang baik (nada, intonasi, ekspresi), dan kemampuan untuk mendengar.

Ketiga, Penguasaan dan antusiasme terhadap materi pelajaran. Seorang peserta didik dituntut untuk menguasai materi pelajaran dengan benar, jika materi telah dikuasainya maka materi dapat diorganisasikan secara sistematis dan logis. Seorang pendidik harus mampu menghubungkan materi yang diajarkannya dengan pengetahuan yang telah dimiliki para peserta didiknya, mampu mengaitkan materi dengan perkembangan yang sedang terjadi sehingga kegiatan pembelajaran menjadi hidup.

Keempat, Sikap positif terhadap peserta didik. Sikap positif terhadap peserta didik dapat tercermin dalam beberapa hal, antara lain: a). Pendidik memberi bantuan jika peserta didik mengalami kesulitan dalam memahami materi yang diberikan; b). Pendidik mendorong para peserta didiknya untuk mengajukan pertanyaan atau memberi pendapat; c). Pendidik dapat dihubungi oleh peserta didiknya di luar jam pelajaran; d). Pendidik menyadari dan peduli dengan apa yang dipelajari peserta didiknya.

Kelima, Pemberian nilai yang adil. Keadilan dalam pemberian nilai tercermin pada: a) Kesesuaian soal tes dengan materi yang diajarkan; b) Sikap konsisten terhadap pencapaian tujuan pembelajaran; c) Usaha yang dilakukan peserta didik untuk mencapai tujuan; d) Kejujuran peserta didik dalam memperoleh nilai; e) Pemberian umpan balik terhadap hasil pekerjaan peserta didik.

Keenam, Keluwesan dalam pendekatan pembelajaran. Pendekatan yang luwes dalam pembelajaran dapat tercermin dengan adanya kesempatan waktu yang berbeda diberikan kepada peserta didik yang memang mempunyai kemampuan yang berbeda. Kepada peserta didik yang

\footnotetext{
${ }^{7}$ Hamzah B. Uno dan Mohammad Nurdin, Belajar dengan Pendekatan PAILKEM, (Jakarta: PT. Bumi Aksara, 2012), h. 174.
} 
mempunyai kemampuan yang rendah diberikan kesempatan untuk memperoleh tambahan waktu dalam kegiatan remedial. Sebaliknya, kepada peserta didik yang mempunyai kemampuan di atas rata-rata diberikan kegiatan pengayaan. Dengan demikian, peserta didik memperoleh pelayanan yang sesuai dengan kemampuan mereka.

Ketujuh, Hasil belajar peserta didik yang baik. Evaluasi adalah satusatunya cara untuk menentukan ketepatan dan keberhasilan pembelajaran. Dengan demikian, dapat dikatakan bahwa indikator pembelajaran efektif dapat diketahui dari hasil belajar peserta didik yang baik. Petunjuk keberhasilan belajar peserta didik dapat dilihat bahwa peserta didik tersebut menguasai materi pelajaran yang diberikan. Dalam konsep belajar tuntas ukuran penguasaan materi atau ketuntasan belajar ditetapkan antara $75 \%$ $90 \%$. Artinya bahwa pembelajaran disebut efektif apabila setiap peserta didik sekurang-kurangnya dapat menguasai $75 \%$ dari materi yang diajarkan atau memperoleh 75 .

Saat ini banyak metode pembelajaran yang telah dikembangkan dan diterapkan di sekolah-sekolah. Semua itu dilakukan agar proses pembelajaran yang terjadi berjalan dengan lebih menarik, tidak membosankan, dan tentu saja efektif dalam mencapai tujuan pembelajaran yang telah ditetapkan. Salah satu metode yang saat ini mulai banyak dikembangkan dan telah terbukti efektif dalam mengoptimalkan kegiatan pembelajaran di sekolah adalah metode pembelajaran hypnoteaching.

\section{Hypnoteaching}

Pikiran adalah anugerah terbesar yang dianugerahkan Tuhan kepada manusia. Dengan pikiran manusia mampu membangun budaya yang begitu kompleks yang terus berkembang seiring perkembangan pikiran manusia. Pikiran manusia ini dikendalikan oleh organ yang bernama otak. Kemampuan otak manusia inilah yang membedakan manusia dengan makhluk Tuhan yang lain.

Berdasarkan cara kerjanya, otak manusia dapat dibagi menjadi otak kiri yang bekerja secara sadar, dan disebut pikiran sadar, dan otak kanan yang bekerja tanpa disadari dan disebut pikiran bawah sadar. Pikiran sadar (conscious) memegang peranan hanya $12 \%$ terhadap kesuksesan kita. Sementara peranan yang $88 \%$ dipegang oleh pikiran bawah sadar (subsconscious). Maka dari itu hampir semua aktivitas kita sebenarnya dikendalikan oleh alam bawah sadar termasuk diantaranya penyimpanan data atau pengetahuan yang kita peroleh ${ }^{8}$.

\footnotetext{
${ }^{8}$ Wandi. R, Kaya dan Sukses dengan Kehebatan Pikiran Bawah Sadar, (Jogjakarta: Sinar Kejora,
} 
Ketika pikiran bawah sadar anak sering diisi dengan hal-hal negatif seperti ungkapan-ungkapan "kamu bodoh, kamu malas, kamu tidak bisa melakukan apa-apa", secara tidak sadar kata-kata tersebut akan terbawa hingga anak itu dewasa. Ketika anak diminta melakukan hal baru, dalam hati anak itu timbul ketakutan, "apakah aku bisa melakukannya?" dan sebagainya. Pikiranpikiran seperti itu adalah salah satu faktor penghambat kesuksesan yang harus segera disingkirkan. Bagaimana caranya? Tentu saja harus kita lawan dengan memasukkan kata-kata yang positif ke pikiran bawah sadar anak, seperti "kamu pintar, kaтu bisa, kamu hebat" dan sebagainya, karena apa yang masuk dalam otak bawah sadar melalui sugesti akan diterima sepenuhnya sebagai suatu kebenaran.

Untuk menembus filter bawah sadar seseorang dan memasukkan sugestisugesti positif dengan mudah adalah melalui hipnosis ${ }^{9}$. Hipnosis adalah suatu seni, metode, atau teknik berkomunikasi yang sangat persuasif dan sugestif dengan tujuan supaya suatu hal yang menjadi maksud kita dapat dipahami dengan mudah oleh lawan bicara. Disinilah keterkaitan antara hipnosis dan pengajaran yang kemudian disebut dengan hypnoteaching. Kata hipnosis telah lama digunakan, yaitu sebelum tahun 1900-an oleh James Braid, ia adalah seorang ahli bedah yang berasal dari Skotlandia. Hipnosis telah menjelaskan bahwa adanya fenomena trans akibat adanya tidur saraf yang muncul karena perhatian terfokus pada sebuah objek tertentu. Hipnosis dapat diartikan sebagai sebuah kondisi relaks, fokus atau konsentrasi yang menjadi ciri khas dari kondisi tersebut adalah sensor-sensor pancaindera manusia menjadi lebih aktif. ${ }^{10}$

Hypnoteaching merupakan perpaduan dari dua kata, yaitu hipnosis dan teaching. Hipnosis berarti mensugesti dan teaching yang berarti mengajar ${ }^{11}$. Jadi hypnoteaching adalah usaha untuk menghipnosis atau mensugesti anak didik supaya menjadi lebih baik dan prestasinya meningkat. Hypnoteaching adalah seni berkomunikasi dengan jalan memberikan sugesti agar para siswa menjadi lebih cerdas $^{12}$. Lebih lanjut dijelaskan bahwa dalam hypnoteaching penyajian materi pelajaran menggunakan bahasa-bahasa bawah sadar yang menimbulkan sugesti siswa untuk berkonsentrasi secara penuh pada ilmu yang disampaikan oleh guru.

2011), h. 8

${ }_{9}^{9}$ Lucy, Bunda Lucy, 5 Menit Menguasai Hypnoparenting, (Jakarta: Penebar Plus. 2012), h. 86.

${ }^{10}$ Muhammad Anwar. HM, Mengajar dengan Teknik Hipnosis (Teori dan Praktek), (Jakarta: Yayasan Yapma, 2014), h. 79-80.

${ }^{11}$ Yustisia, N, Hypnoteaching, (Jogjakarta: Ar-Ruzz Media, 2012), h. 75.

${ }^{12}$ Ibnu Hajar, Hypnoteaching, (Jogjakarta:Diva Press, 2012), h. 75. 
Dari beberapa pengertian hypnoteaching sebagaimana uraian di atas, maka dapat disimpulkan bahwa hypnoteaching adalah metode pembelajaran yang dalam menyampaikan materi pelajaran, guru menggunakan teknik berkomunikasi yang sangat persuasif dan sugestif dengan tujuan agar peserta didik mudah memahami materi pelajaran. Pikiran bawah sadar dengan mudah menyerap hal yang negatif, tidak memotivasi, dan menjatuhkan. Oleh karena itu, hati-hati dalam menggunakan kata-kata karena hal tersebut bisa berdampak buruk terhadap kualitas peserta didik. ${ }^{13}$ Hypnoteaching menekankan pada komunikasi alam bawah sadar siswa yang dapat dilakukan dengan berbagai cara, seperti sugesti dan imajinatif. Kemampuan sugesti yang terus terngiang dalam otak, mampu mengantarkan seseorang pada apa yang dipikirkannya. Sedangkan imajinasi merupakan proses membayangkan sesuatu terlebih dahulu baru melakukannya. Dalam hal ini seorang guru harus mampu membiarkan peserta didiknya berekspresi dan berimajinasi. Hipnosis merupakan kondisi ketika seseorang menerima saran, informasi, dan sugesti tertentu yang mampu mengubah seseorang dari hal yang kurang baik menjadi hal yang lebih baik. ${ }^{14}$

Hal pertama yang perlu dipahami dalam memberikan sugesti kepada peserta didik disarankan untuk menggunakan kalimat positif. Hypnosis merupakan teknik komunikasi, sehingga bahasa memegang peranan yang sangat penting ${ }^{15}$. Oleh karena itu, bahasa yang digunakan dalam proses hypnosis harus singkat dan jelas, mudah dipahami anak, mengandung kepastian, hindari menggunakan kata mungkin, seandainya, dan lain-lain, disesuaikan tingkat intelektualitas anak, disesuaikan dengan usia perkembangan anak, gunakanlah kata-kata positif dan ulangi berkali-kali, sebaliknya hindari menggunakan katakata negatif, tidak menggunakan kata "harus" yang terkesan memaksa anak, hindari penggunaan kata-kata "tidak", "bukan", dan "jangan".

Seorang guru, pengajar, dan pendidik selayaknya memiliki kebiasaan dalam berkata positif. Tentunya kebiasaan ini hanya bisa berjalan jika setiap guru melatihnya setiap hari. Setiap kata-kata yang sekiranya negatif sebaiknya dibuang jauh-jauh dari pikiran. ${ }^{16}$ Oleh karena itu, penerapan metode hypnoteaching dalam kegiatan pembelajaran, dilakukan dengan menggunakan kata-kata atau kalimat yang terkesan tidak menyulitkan dan memberatkan peserta

\footnotetext{
13 Muhammad Anwar. HM, Mengajar dengan Teknik Hipnosis (Teori dan Praktek), (Jakarta: Yayasan Yapma, 2014), h. 217.

14 Muhammad Anwar. HM, Mengajar dengan Teknik Hipnosis (Teori dan Praktek), (Jakarta: Yayasan Yapma, 2014), h. 90.

${ }^{15}$ Lucy, 5 Menit Menguasai Hypnoparenting, (Jakarta: Penebar Plus, 2012), h. 75.

16 Muhammad Anwar. HM, Mengajar dengan Teknik Hipnosis (Teori dan Praktek), (Jakarta: Yayasan Yapma, 2014), h. 216.
} 
didik dalam mengikuti pelajaran. Contoh kalimat-kalimat tersebut adalah:

a) Baiklah, anak-anakku yang pintar dan hebat, kali ini kita akan mempelajarai materi yang sangat menarik! tentu saja materi ini akan sangat bermanfaat dalam kehidupan sehari-hari jika kalian berhasil menguasainya;

b) Bapak/ibu selalu yakin, pasti kalian bisa mengerjakan latihan-latihan ini dengan baik dan tepat;

c) Meskipun soal ini sepertinya sulit, bapak/ibu akan memberikan trik yang bisa dilakukan agar kita dapat mengerjakan soal dengan lebih cepat dan mudah;

d) Meskipun materi kali ini cukup banyak, tapi dengan konsentrasi dan ketekunan, kalian pasti akan bisa menguasainya.

\section{Langkah-langkah Hypnoteaching dalam Menciptakan Pembelajaran Efektif}

Penerapan hypnoteaching untuk menciptakan pembelajaran efektif, dilakukan melalui langkah-langkah tertentu ${ }^{17}$. Langkah-langkah yang dimaksud adalah sebagai berikut;

Pertama, Niat dan motivasi dalam diri sendiri. Kesuksesan seseorang dalam berbagai bidang pekerjaan yang menjadi profesinya tergantung pada niat atau keinginan dalam hati untuk berusaha dan bekerja keras dalam mencapai kesuksesan tersebut. Sebab niat yang besar akan memunculkan motivasi yang tinggi dan komitmen untuk selalu mencurahkan segala perhatian dan energi yang dimilikinya untuk bidang yang ditekuninya. Oleh karena itu, niat guru dalam mengajar hendaknya tidak sekadar untuk menyampaikan materi pelajaran tapi lebih dari itu ingin membangun masa depan peserta didik, bangsa dan negara. Jika demikian niat guru dalam mengajar maka tentu guru tersebut akan memiliki motivasi dan komitmen yang tinggi untuk mencurahkan segala potensi yang dimilikinya untuk mencerdaskan peserta didiknya.

Kedua, Pacing. Pacing berarti menyamakan posisi, gerak tubuh, bahasa, serta gelombang otak dengan orang lain atau peserta didik. Karena pada prinsipnya manusia cenderung atau lebih suka berinteraksi dengan teman yang memiliki banyak kesamaan, sehingga ia akan merasa nyaman. Dengan kenyamanan yang bersumber dari kesamaan gelombang otak inilah, maka setiap pesan yang disampaikan dari satu orang ke orang lain bisa diterima dan dipahami dengan baik.

Hal tersebut juga berlaku dalam penerapan metode hypnoteaching dalam pembelajaran. Guru yang mengajar di Taman Kanak-kanak (TK) misalnya tentu akan menggunakan bahasa yang mudah dimengerti oleh anak-

\footnotetext{
${ }^{17}$ Ibnu Hajar., 2012. Hypnoteaching. (Jogjakarta:Diva Press, 2012), h. 100
} 
anak usia TK dalam berkomunikasi dengan mereka. Jadi meskipun usia guru jauh lebih tua daripada peserta didiknya, namun gelombang otak sebenarnya dapat disetarakan dengan seakan-akan melakukan atau berpikir seperti mereka.

Ada beberapa cara dalam melakukan pacing terhadap siswa dalam kegiatan pembelajaran, yaitu:

a) Bayangkan usia kita setara dengan peserta didik, sehingga kita dapat melakukan aktivitas dan merasakan hal-hal yang dialami oleh mereka saat ini;

b) Gunakan bahasa sesuai dengan bahasa yang sering digunakan oleh peserta didik;

c) Lakukan gerakan-gerakan dan mimik wajah yang sesuai dengan tema bahasan;

d) Sangkutkan tema pelajaran kita dengan tema-tema yang sedang tren di kalangan peserta didik;

e) Selalu update pengetahuan tentang tema, bahasa, gosip terbaru yang sedang tren di kalangan peserta didik.

Dengan melakukan hal-hal tersebut, maka tanpa sadar gelombang pikiran kita telah sama dengan para peserta didik, sehingga mereka merasa nyaman untuk bertemu dengan kita.

Ketiga, Leading. Leading memiliki pengertian memimpin atau mengarahkan sesuatu. Setelah melakukan pacing, para siswa akan merasa nyaman dengan guru. Pada saat itulah hampir setiap apapun yang guru ucapkan atau tugaskan kepada mereka, akan dilakukan dengan suka rela dan senang hati. Sehingga sesulit apapun materinya, pikiran bawah sadar mereka akan menangkap materi pelajaran dengan mudah. Sebaliknya jika kita melakukan leading tanpa didahului dengan pacing, maka hal itu sama saja dengan memberikan perintah kepada para peserta didik yang cukup berisiko, karena mereka melakukannya dengan terpaksa dan tertekan. Hal ini akan berakibat pada penolakan mereka kepada guru. Dalam ilmu Linguistic Programming (NLP), dikenal dengan istilah pacing-leading, seorang guru berusaha untuk memasuki persepsi atau pandangan peserta didik tentang pendapat, ide dan gagasannya berdasarkan fakta terlebih dahulu. Dengan demikian, saat persepsi atau pandangan antara guru dan peserta didik telah memiliki kesamaan, seorang guru menunggu saat yang tepat untuk mengarahkan peserta didik dengan saran-saran yang membangun. ${ }^{18}$

Keempat, Gunakan kata-kata positif. Penggunaan kata positif ini sesuai dengan cara kerja pikiran bawah sadar yang tidak mau menerima kata negatif. Pada dasarnya kata-kata yang diberikan oleh guru, baik langsung maupun tidak, sangat mempengaruhi kondisi psikis para siswa, sehingga

${ }^{18}$ Muhammad Anwar. HM, Mengajar dengan Teknik Hipnosis (Teori dan Praktek), (Jakarta: Yayasan Yapma, 2014), h. 162. 
mereka merasa lebih percaya diri dalam menerima materi yang diberikan. Kata-kata tersebut dapat berupa ajakan dan himbauan.

Jadi apabila ada hal-hal yang tidak boleh dilakukan oleh mereka, hendaknya menggunakan kata ganti yang positif untuk mengganti kata-kata negatif. Sebagai contoh apabila akan menenangkan kelas yang ramai (ribut), biasanya kata perintah yang keluar adalah, "Jangan ribut!" Dalam mengaplikasikan hypnoteaching, hendaknya kata-kata jangan ribut ini diganti dengan, "Mohon tenang."

Kelima, Berikan pujian. Salah satu hal yang paling penting dalam pembelajaran adalah reward and punishment. Pujian merupakan reward atas peningkatan harga diri seseorang. Pujian merupakan salah satu cara untuk membentuk konsep diri seseorang. Maka dari itu, berikanlah pujian kepada para peserta didik dengan tulus, sehingga mereka akan terdorong untuk melakukan yang lebih baik dari yang sebelumnya. Pemberian pujian bisa dilakukan ketika peserta didik berhasil melakukan atau mencapai prestasi. Berikanlah pujian sekecil apapun bentuk prestasinya, termasuk ketika ia berhasil melakukan perubahan positif pada dirinya sendiri.

Dalam memberikan pujian hindari kata penghubung negatif, misalnya "tapi", "namun", "cuma saja”, dan lain sebagainya. Menggunakan kata-kata tersebut akan membuat pujian kita sia-sia dan terkesan mengolok-olok, seperti pada perkataan, "Budi, kamu itu anak yang pandai, ibu/bapak senang sekali punya peserta didik seperti kamu, tapi sayangnya kamu kurang memperhatikan kerapian pakaianmu". Cara untuk menghindari kata penghubung negatif adalah dengan menghilangkan kata penghubung tersebut. Misalnya, "Kamu adalah peserta didik yang pandai dan sangat membanggakan. Akan lebih membanggakan lagi kalau kamu lebih memperhatikan kerapian penampilanmu".

Keenam, Modeling. Modeling adalah proses memberi teladan atau contoh melalui ucapan dan perilaku yang konsisten dan merupakan salah satu kunci keberhasilan dalam hypnoteaching. Setelah peserta didik merasa nyaman dengan guru, maka ia perlu memantapkan perilakunya agar konsisten dengan ucapan dan ajarannya, sehingga ia selalu menjadi figur yang dipercaya. Dalam salah satu tulisannya mengenai pendidikan yg berjudul "Menjadi Guru di Masa Kebangunan", Bung Karno memulai risalahnya dengan kutipan :"Anda tidak bisa mengajarkan apa yang Anda mau. Anda tidak bisa mengajarkan apa yang Anda tahu. Anda hanya bisa mengajarkan siapa Anda". Ungkapan tersebut mengandung makna bahwa contoh itu lebih mujarab dari pada nasihat atau perintah. Oleh karena itu, guru haruslah menjadi sosok yang pantas untuk digugu dan ditiru. Digugu berarti dipercaya ucapannya dan ditiru berarti dicontoh perilakunya.

Jika langkah-langkah hypnoteaching tersebut terimplementasi dalam 
kegiatan pembelajaran, maka suasana pembelajaran di kelas akan lebih kondusif, semua peserta didik merasa penting, aman dan nyaman serta termotivasi mengikuti pelajaran. Dengan demikian peserta didik akan lebih mudah menerima dan memahami materi pelajaran sehingga tujuan pembelajaran lebih mudah tercapai.

\section{Simpulan}

Mencermati uraian di atas, maka dapat disimpulkan bahwa pembelajaran efektif adalah suatu pembelajaran yang memungkinkan peserta didik untuk dapat belajar dengan mudah, menyenangkan, dan dapat tercapai tujuan pembelajaran yang telah ditetapkan. Salah satu metode yang dapat digunakan untuk menciptakan pembelajaran efektif adalah metode hypnoteaching yaitu metode pembelajaran yang dalam menyampaikan materi pelajaran, guru menggunakan teknik berkomunikasi yang sangat persuasif dan sugestif dengan tujuan agar peserta didik mudah memahami materi pelajaran.

Langkah-langkah hypnoteaching dalam menciptakan pembelajaran efektif meliputi: a). Niat dan motivasi dalam diri sendiri; b). Pacing atau menyamakan posisi, gerak tubuh, bahasa, serta gelombang otak dengan peserta didik; c). Leading atau mengarahkan; d). Menggunakan kata-kata positif; e). Memberikan pujian; f). Modeling atau memberi teladan melalui ucapan dan perilaku.

\section{Referensi}

Anwar. HM, Muhammad, Mengajar dengan Teknik Hipnosis (Teori dan Praktek), Jakarta: Yayasan Yapma, 2014.

Hajar, Ibnu, Hypnoteaching. Jogjakarta: Diva Press, 2012.

Lucy, Bunda, 5 Menit Menguasai Hypnoparenting. Jakarta: Penebar Plus, 2012.

Peraturan Pemerintah Nomor 32 Tahun 2013 tentang Standar Nasional Pendidikan.

Peraturan Menteri Pendidikan dan Kebudayaan Nomor 65 Tahun 2013 tentang Standar Proses Pendidikan Dasar dan Menengah.

Sanjaya, Wina, Strategi Pembelajaran, Jakarta: Kencana Prenada Media Group, 2007.

Sutikno, M.Sobry, Pembelajaran Efektif, Mataram: NTP Press, 2005.

Uno. B, Hamzah dan Mohammad Nurdin, Belajar dengan Pendekatan PAILKEM. Jakarta: PT. Bumi Aksara, 2012.

Y.A Wandi, R, Kaya dan Sukses dengan Kehebatan Pikiran Bawah Sadar, Jogjakarta Sinar Kejora, 2012.

Yustisia, N, Hypnoteaching, Jogjakarta: Ar-Ruzz Media, 2012. 